\title{
Beef, pork and mutton: An archaeological survey of meat consumption in medieval and postmedieval towns in the southern Low Countries (Flanders \& Brussels, Belgium)
}

\author{
Anton Ervynck ${ }^{\mathrm{a},{ }^{*}, \text { Wim Van Neer }}{ }^{\mathrm{b}, \mathrm{c}}$ \\ a Flanders Heritage, Koning Albert II-laan 19 box 5, B-1210 Brussels, Belgium \\ ${ }^{\mathrm{b}}$ Royal Belgian Institute of Natural Sciences, Vautierstraat 29, B-1000 Brussels, Belgium \\ ${ }^{c}$ Laboratory of Biodiversity and Evolutionary Genomics, KU Leuven, Ch. Debériotstraat 32, B-3000 Leuven, Belgium
}

\section{A R T I C L E I N F O}

\section{Article history:}

Received 17 January 2016

Received in revised form

20 January 2017

Accepted 5 February 2017

Available online $\mathrm{xxx}$

\section{Keywords:}

North-western Europe

Middle ages

Postmedieval period

Urban economy

Meat consumption

Town-countryside relationships

\begin{abstract}
A B S T R A C T
A survey is presented of archaeozoological information from medieval and postmedieval towns in the southern Low Countries (the present regions of Flanders and Brussels, in Belgium). Diachronic changes in the consumption of the three main domestic meat-suppliers (cattle, pig, sheep) in nine towns are investigated, and trends are compared among these towns. At the same time, possible geographical differences in meat consumption are traced. The observed differences in time and space are then explained as part of the economics of animal husbandry and of the interaction between town and countryside. From a methodological standpoint, this survey demonstrates that in a number of cases, information from archaeozoological contexts with varying depositional histories, often reflecting different socio-economic strata, can be combined to obtain a picture of meat consumption, and thus of the town's food provisioning, through time.
\end{abstract}

(๑) 2017 Elsevier Ltd and INQUA. All rights reserved.

\section{Introduction}

Urbanisation is one of the key characteristics of the post-Roman socio-economic development of the Low Countries (see 2. for an explanation of this geographical term), starting at the end of the first millennium AD and continuing until the present day (see Verhulst, 1999; for general historical context). Few of the developing medieval towns had a strong link with a Roman predecessor (Verhulst, 1999, p.1-23); most of these towns must thus be seen as innovations, representing a new element in the medieval economy. From the start, this novel way of social organisation presented economic challenges. Because the towns' inhabitants were not primarily involved in agrarian activities, this growing group of consumers depended upon food production that took place elsewhere. Some organisation needed to be maintained in order to ensure a steady supply of food, thereby enabling the urban merchants, craftspeople, artists and labourers to continue their core

\footnotetext{
* Corresponding author.

E-mail addresses: anton.ervynck@rwo.vlaanderen.be (A. Ervynck),wvanneer@ naturalsciences.be (W. Van Neer).
}

businesses. The development of urban markets, or commercial networks in general, selling products from the countryside to the towns' inhabitants, was the obvious solution, although goods were doubtlessly also transferred through other pathways. Some of the towns' inhabitants owned large estates in the countryside, while others tried to maintain food production within the town walls. Both groups can thus be seen as producers too.

The feeding of medieval (and postmedieval) towns is a research theme that has gained some interest within European archaeozoology (see, e.g., Bartosiewicz, 1995; Lauwerier, 1997; O'Connor, 2003; Albarella, 2005). The consumption of meat has usually been the focus of attention, and research has demonstrated that beef, pork and mutton have always been the most important sources of animal protein for urban households. Of course, the contribution of fish and shellfish cannot be ignored, but recent stable isotope studies suggest that these animal groups did not contribute substantially to the protein intake (Ervynck et al., 2014). Based on their low find numbers, the latter conclusion is equally true for birds or wild mammals. The main questions arising from the archaeozoological analysis of medieval and later urban archaeological assemblages, at least in north-western Europe, thus concern the way in which cattle, sheep and pig reached urban 
consumers. Did these animals represent surplus production from the herds kept in the countryside? If so, we must ask how this 'roaming off' was organised. Or, alternatively, were certain herds solely kept as meat suppliers for the urban consumers? Or, as is often stated in - mostly - popular texts, did townspeople try to breed animals within the town walls (letting them roam the streets looking for all sorts of refuse) as a means to escape their dependency on producers outside of the town's control?

A major problem for the study of food provisioning in medieval towns is that, despite this research being part of what is called 'historical archaeology', the questions asked largely escape the reach of historical studies. One can look in the towns' archives for detailed accounts of animals coming in to be slaughtered, but such accounts are rare (but see, e.g., Van Uytven, 1985) and none predate the late Middle Ages (see 2. for chronological terms). On the other side of the market economy, records documenting the behaviour of the consumers are equally rare, and these pertain only to late-medieval and postmedieval, often rich, households, which, moreover, are not representative of the majority of urbanites because they could partly escape the constraints of the urban market economy (see Dyer, 1997; Woolgar, 1992-93). It is therefore certainly useful to study such aspects as daily nutrition through the analysis of the consumption refuse excavated from medieval and later towns, although these material remains also present a wealth of interpretational problems (see O'Connor, 2003).
Around the turn of the first to the second millennium $\mathrm{AD}$, the southern part of the Low Countries was a pioneering European region in terms of the development of urban economies, second only to the northern part of present-day Italy (Verhulst, 1999; Pounds, 2005) (Fig. 1). It is often noted that during the 13th century Gent was the largest town north of the Alps after Paris (e.g., Zajac and Deckmyn, 2009). These two factors make the region an interesting study area for archaeozoological analyses into the meat supply of medieval and later towns. In fact, rather early in the development of archaeozoology in Belgium, faunal assemblages from Gent were being analysed diachronically, leading to hypotheses about trends in the meat consumption of that town (Van der Plaetsen, 1985, 1986). These hypotheses, however, were criticised by Ervynck (1992). In particular, the idea that the evolution of meat consumption at Gent could be described by the German term Verrinderung (meaning an increase in beef consumption: Abel, 1961) was refuted. The main flaw in the initial analysis was the incorporation into the dataset of archaeozoological assemblages from households, such as castles or monastic houses, which hardly took part in the urban economy because they had possessions in the countryside. Moreover, the meat consumption within these households was strongly influenced by social mechanisms that necessitated a display of status (through conspicuous consumption; Ervynck, 2004) or by religious dietary rules (Ervynck, 1997).

At the York 'Medieval Europe' conference in 1992, a new

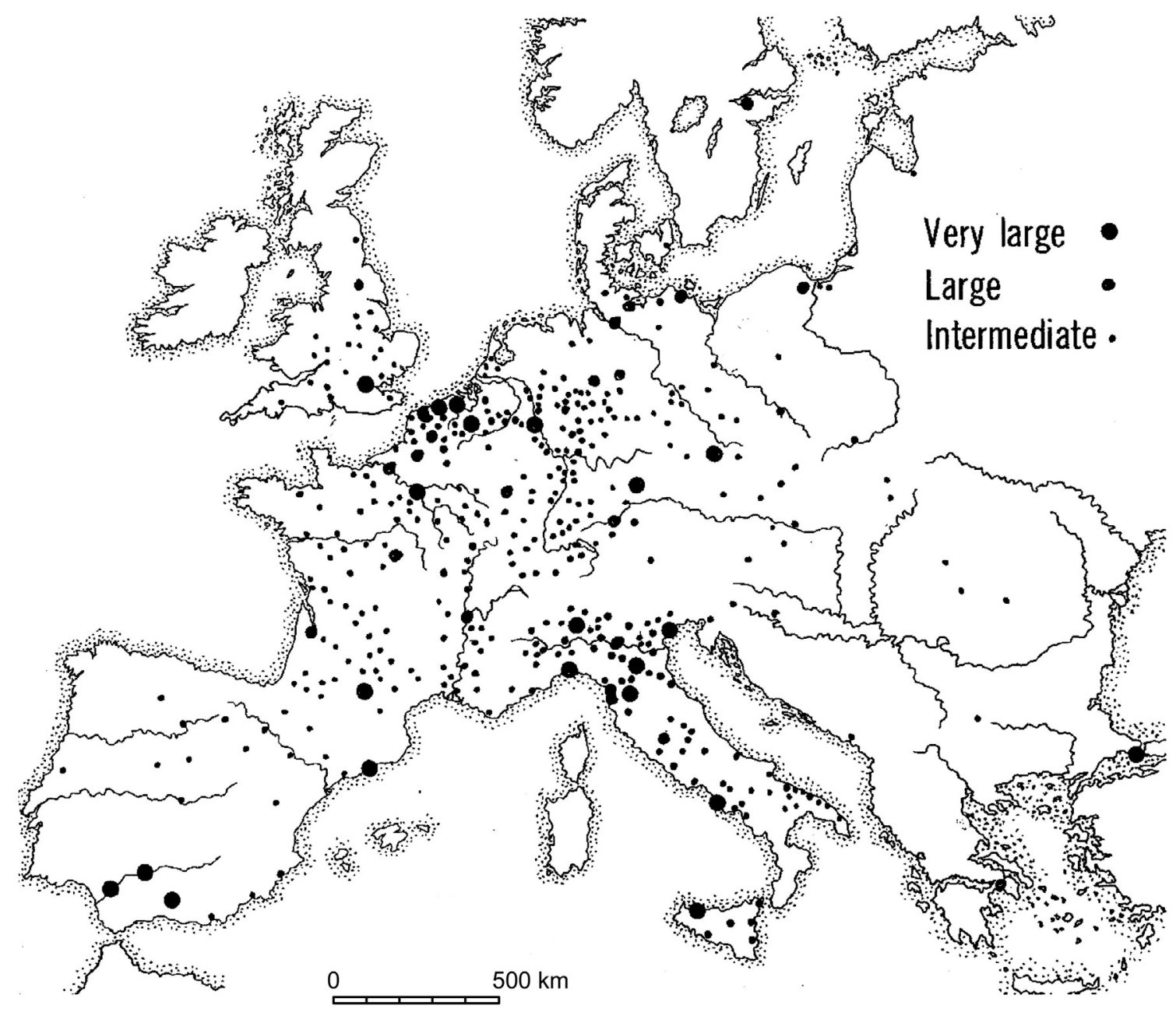

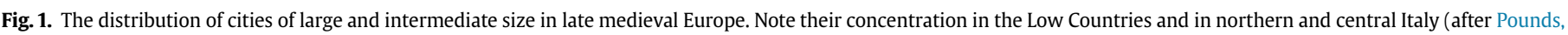
2005, p. 76, Fig. 19). 
interpretation for the dataset from Gent was put forward (Ervynck, 1992), but, at that time, not enough data from other towns from the southern Low Countries were available in order to check whether the patterns observed were merely anecdotal or valid for a wider range of sites. In the present contribution, we survey the archaeozoological information gained through continued urban archaeology during the nearly 25 years following the York gathering. Noteworthy is that it is now possible to deal with data from many more towns besides Gent. The analysis focuses on whether the relative frequencies of the main domestic meat suppliers (cattle, pig, sheep) reveal trends through time or space that could help us to understand the mechanisms of the medieval and later towns' meat supply. The focus lies not on the history of the towns themselves but, rather, on general trends in urban food provisioning within the study area.

\section{Study area and chronological context}

The sites discussed in the present survey are located in the northern part of Belgium, covering the present-day federal entities of Flanders and the Brussels-Capital Region. The study area is located in the southern part of the Low Countries, a term that is commonly used to describe the low-lying lands bordering the Channel and the North Sea, now part of north-western France, Belgium above the Sambre-and-Meuse line, and The Netherlands. It should be noted that such terms as Flanders have changed considerably in both territorial and political meaning through time. As an example, towards the end of the Middle Ages, our study area, today called Flanders and Brussels-Capital Region, comprised parts of (amongst others) the former County of Flanders, the Duchy of Brabant, the Prince-Bishopric of Liège and the County of Loon. Throughout the text, we use the names for the towns that are currently in use (i.e. the Dutch versions), although it should be noted that Brussels is now more commonly known as Bruxelles by its majority of French-speaking inhabitants. Note that in this text, Brussels refers to the Capital Region, not only to the town.

Geographically, the study area comprises a number of regions, which can be delimited and named in many, slightly different ways, depending on the parameters taken into account: quaternary (or older) geology, geomorphology, soil types, land use, etc. In this survey, the landscape will be described in terms of the geobotanical districts (Massart, 1910; Tanghe, 1975) (Fig. 2), on the assumption that these subdivisions represent the end result of the interaction between the parameters mentioned above (and other factors, such as climate). In short, the Littoral and Alluvial District comprises low-lying lands near the sea or the estuary of the river Scheldt and in the river valleys, which are covered by Holocene (clay) sediments. The Flemish District is characterised by sandy soils of Pleistocene origin, while the more elevated and hilly Hesbay District shows a north-south transition from Pleistocene sand-loam to loamy soils. The 'flat' Campine District has poor, Pleistocene sandy soils. Over the course of the second millennium $A D$, the landscape in these districts changed considerably. It is beyond the scope of this survey to critically review these anthropogenic evolutions (see Verhulst, 1990, for a general description of the development of agriculture in Belgium, from the early Middle Ages to the end of the postmedieval period), but the following processes are the most important to remember. Starting from around the end of the first millennium AD and ending towards the 12th century, the Littoral and Alluvial District, especially the part bordering the sea and the Scheldt estuary, changed from being an area under influence of the tides to being an embanked landscape of mainly grasslands, locally known as polders (see Verhulst, 1995). The Flemish and Hesbay Districts evolved from a forested region into an open, agricultural landscape, a process that was especially active in the period from the 10th to the middle of the 13th century AD, with lasting results (Tack et al., 1993). Finally, deforestation and animal herding had turned the Campine District into an area dominated by heath-land towards the late Middle Ages (Arts et al., 2007).

In terms of chronology, within the historical context of the study area, the term Middle Ages designates the period from the 5th to 15 th centuries $A D$, which is subdivided into the early Middle Ages (5th to 9th centuries AD), the high Middle Ages (10th to 12th centuries AD) and the late Middle Ages (13th to 15th centuries AD). The so-called postmedieval period starts in the 16th century AD and ends around 1800 AD (Slechten, 2004).

\section{Material and methods}

The faunal assemblages used in this survey derive from a large number of excavations on the territories of Brussel and a number of Flemish towns. The quality of the excavations supplying archaeozoological information, and the resulting faunal assemblages, vary widely, an understandable phenomenon given the fact that almost all urban sites were explored under circumstances that must be described as 'rescue archaeology'. The earliest of these excavations were carried out by volunteers. As Belgian archaeology evolved, excavations came to be carried out by town archaeologists and their

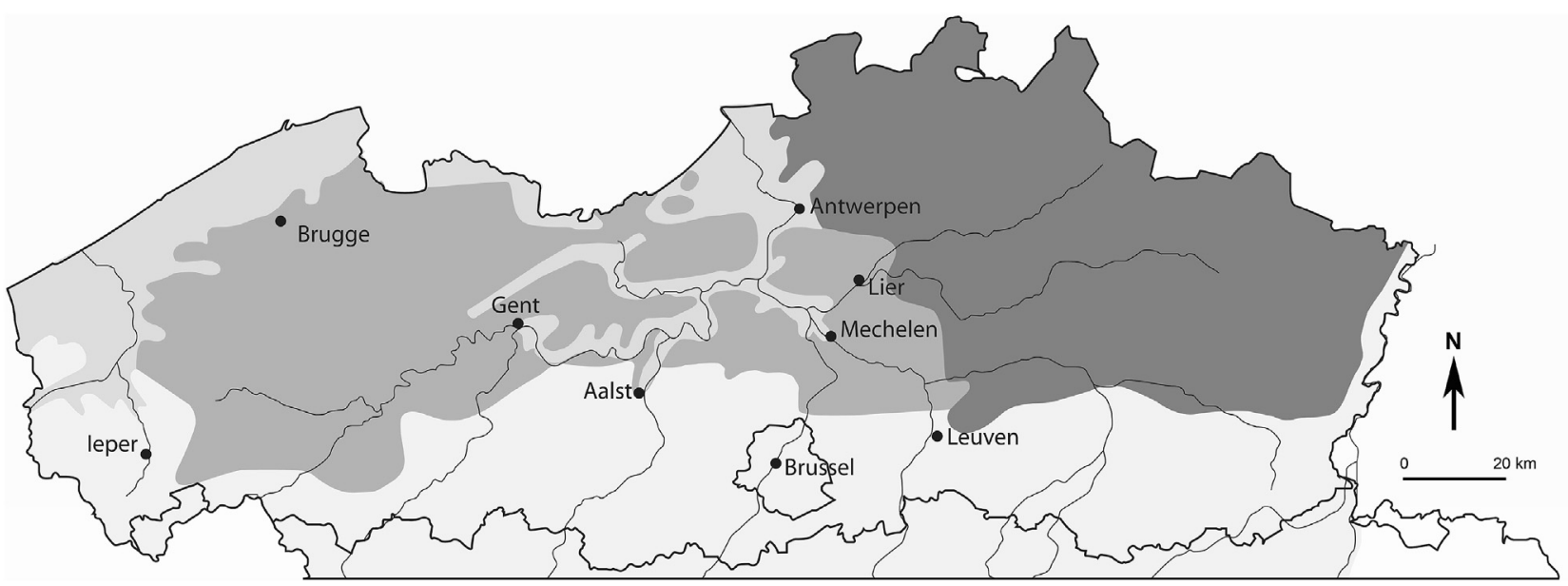

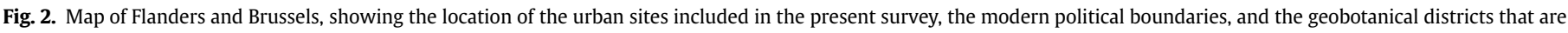
part of the study area (white: Hesbay District, light grey: Littoral and Alluvial District, medium grey: Flemish District, dark grey: Campine District). 
teams, now widely joined by commercial archaeological enterprises. We initially chose to disregard possible differences in recovery methodology, and used as many assemblages as were available for this survey, given the fact that all material has been handcollected and studied by professional archaeozoologists. The data collection was concluded in Spring 2015.

The criteria we used to designate an assemblage as coming from a historical town match those currently used in local heritage legislation. Towns that have yielded only one or two assemblages that otherwise could have been used for the present survey have been excluded from the analysis. We also excluded assemblages that were not part of the 'urban' economy (mostly feudal strongholds or palaces and monastic houses; see earlier) or did not represent pure consumption refuse, mostly because of an admixture of waste from crafts or of (partial) skeletons from nonconsumed animals. Moreover, we also excluded assemblages lacking a defined depositional history ('stray finds') or representing the result of the unintentional recovery of animal remains ('accidental finds').

For some of the remaining assemblages, the total number of finds from the three main meat suppliers (cattle, pig, sheep) is too low to present a firm basis for statistical analysis. However, the nature of urban excavations in Belgium, mostly only covering small surfaces, necessitates a pragmatic approach, and we have therefore included such assemblages anyway (provided there were sufficient data from elsewhere in the town). There are, of course, additional biasing factors, in that the urban archaeozoological dataset from the southern Low Countries is without a doubt also influenced by taphonomic circumstances (i.e. depositional history) of the contexts analysed (even though we restricted ourselves to consumption refuse); the recovery methods applied (because even within the category hand-collected there may be variation); and the socioeconomic context of the types of archaeological features excavated (even though we excluded noble or monastic households). Still, for reasons of conciseness, within the generalising approach of this survey, these complicating factors will be disregarded. Preservation conditions were always rather good at the study sites, although slight differences will have been present among them. In general, none of the sites presented preservation conditions that were so unfavourable that they would have biased for the preservation of the larger cattle remains versus the smaller sheep and pig remains. Of course, it should be noted in general than none of the assemblages in this dataset can compare with the large, extremely wellpreserved collections from urban sites, sometimes characterised by waterlogged soils, such as York (see O'Connor, 2003, 199-204). Our interpretations must thus be viewed in their proper perspective.

In what follows, we first evaluate the relative frequencies of the finds of cattle, pig and sheep for towns located in present-day Flanders and Brussels. These calculations are based upon the number of identified specimens (NISP), because estimations of minimum numbers of individuals (MNI) seem to be of little use in the complex context of the urban meat economy and garbage disposal (O'Connor, 2003). We stress that the frequencies calculated are all relative and therefore interdependent - which implies that, when the absolute frequency of one species declines, the relative frequencies of the others will rise, even when their absolute frequencies remain constant. To simplify the graphs, we have situated each assemblage chronologically on the basis of the middle value of its date range. For example, a 14th century collection will be placed at $1350 \mathrm{AD}$ on the graph. Of course, this is a crude approach, but we consider it acceptable and practical given that the present survey does not go into detail, certainly not at the level of individual sites.

As a second step in the analysis, we restrict the datasets to the NISP of pig and sheep, calculating the ratio of finds from the first species versus those from the second (the ' $\mathrm{P} / \mathrm{S}$ ratio') (see O'Connor, 2013, 2014 for a similar approach). Interdependency has to be taken into account here too. The reasons to, eventually, exclude cattle from these ratio calculations are manifold. First of all, during handcollecting, less careful recovery will bias against the recovery of smaller items and thereby, all else being equal, bias against the recovery of pig and sheep remains compared with those of cattle. The second reason is that there are marked differences in the ways in which animals were slaughtered and distributed through the urban commercial network. Most probably, pig and sheep were initially more often slaughtered at home. In later periods, when pork and mutton were obtained at market, they will still have been more commonly sold with the bones still attached. In contrast, in general, it can be assumed that towards the postmedieval period gradually fewer and fewer large cattle bones were arriving in the kitchens of smaller households. At the same time, the disposal patterns of large cattle bones can (and will) differ from those of the skeletal remains of smaller livestock. The concept of 'slaughter offal', comprising skull fragments, the vertebral column and the distal limb ends in the case of cattle, is certainly less valid for pig and sheep, because in these species these body parts were traditionally used and highly esteemed (pig and sheep skulls, pigs' trotters, etc.). The third, and perhaps most important, reason is that there is a difference in the distance from which livestock arrived at the urban markets and slaughterhouses. The distance the cattle travelled from their herding grounds could indeed be considerable, validating the use of such terms as 'long distance trade' or 'cattle drives'. Historically, these trade networks are well known for the postmedieval period, but the tradition goes back to late medieval times (Gijsbers, 1999). In contrast, the consumption remains from pig and sheep most likely represent animal products that were reared in areas closer to the town. The fourth and final reason is the fact that each cattle bone represents a much larger meat volume than the corresponding pig or sheep bones. This means that cattle, even when it does not dominate the finds collection, will always have been the main meat supplier (regardless of its culinary status). The dominance of beef could thus obscure trends in the relationship between town and countryside that might be discernible from the data from smaller livestock.

Many studies also take slaughter ages into account when reconstructing the urban meat supply. However, in this analysis we are hampered by the small number of items in many of the assemblages that provide information on tooth eruption and wear or on epiphyseal fusion of the long bones. Moreover, not all of the archaeozoological studies made detailed observations about this aspect, and they certainly did not all follow the same methodology. A thorough investigation of slaughter ages will thus only be possible by revisiting the collections and studying new, larger collections. Therefore only some general remarks can be put forward in this contribution.

\section{Results}

Table 1, in Appendix A, summarises the information from the 89 assemblages incorporated in this survey, and Fig. 2 shows their locations. The nine towns that yielded sufficient information to be included in the dataset are located in the western and central parts of the study area. Brussel is the best documented, by 28 datasets, widely surpassing the next best represented town, Gent (18 datasets). Moderate numbers of faunal collections were available from Antwerpen, Mechelen and Aalst. In Leuven, a large number of contexts have been excavated, be it all from a single excavation. These contexts have been grouped together in the excavation report (Fochplein: Gruwier, 2012), reducing the number of distinct datasets to six. Finally, although Lier, Ieper and Brugge could benefit 
Gent

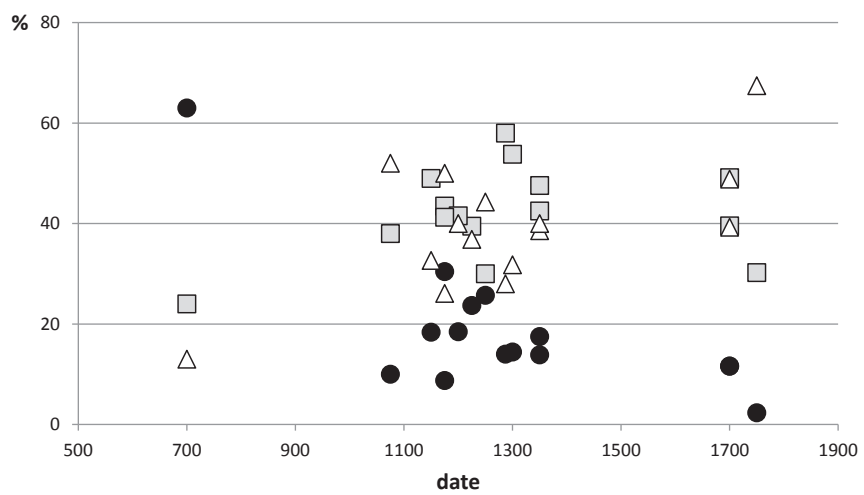

Fig. 3. Relative frequencies of pig (black dots), cattle (grey squares) and sheep (white triangles) for Gent (the assemblages 'Gouvernementstraat 9-11', 'Vrijdagmarkt 14' and 'Vrijdagmarkt 18' have been omitted due to their small sample sizes). Data point ( 1700 12) hides another for pig.

from more archaeozoological information, they nevertheless proved to be useful in the analysis (see below). It should be noted that the date ranges covered by the data widely vary per town (see Table 1 in Appendix A).

When, as a first step, we plotted the relative frequencies of cattle, pig and sheep per town, we obtained varying results. While it is beyond the scope of this survey to describe or analyse the towns individually, we present a few examples to illustrate the differences observed. For Gent, the enlarged dataset (covering the 8th to 18th centuries) confirms the observations made in the 1992 survey (Ervynck, 1992). The remains of pig decline in relative importance through time, while those of sheep increase and those of cattle stay at roughly the same level (Fig. 3). In contrast, the data from Antwerpen (covering the 12th to the early 17th century) suggest a relative decline in cattle, a relative rise in sheep and a continuously low relative frequency of pig (Fig. 4). These trends are also observed at Mechelen, where the data only cover the 14th to 16th centuries (Fig. 5). The combined phases of the dataset from Leuven show patterns more similar to those from Gent (Fig. 6). For other towns, trends are less clear, but this evaluation is of course not at all definitive, since in a number of cases, without doubt, a limited dataset is responsible. It should also be realised that the trends observed in the datasets from Gent, Antwerpen and Mechelen (see Figs. 3-5) do not stand up to statistical scrutiny (analyses not presented here). However, given the many biasing

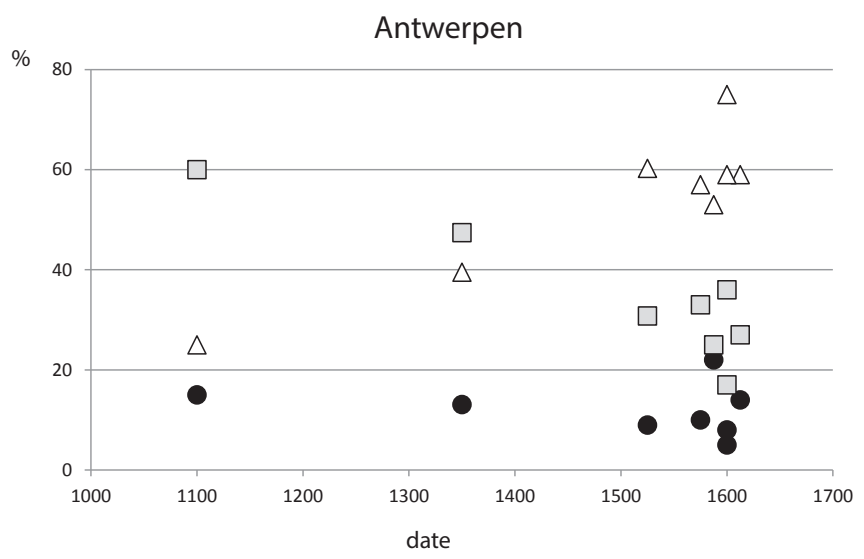

Fig. 4. Relative frequencies of pig (black dots), cattle (grey squares) and sheep (white triangles) for Antwerpen.

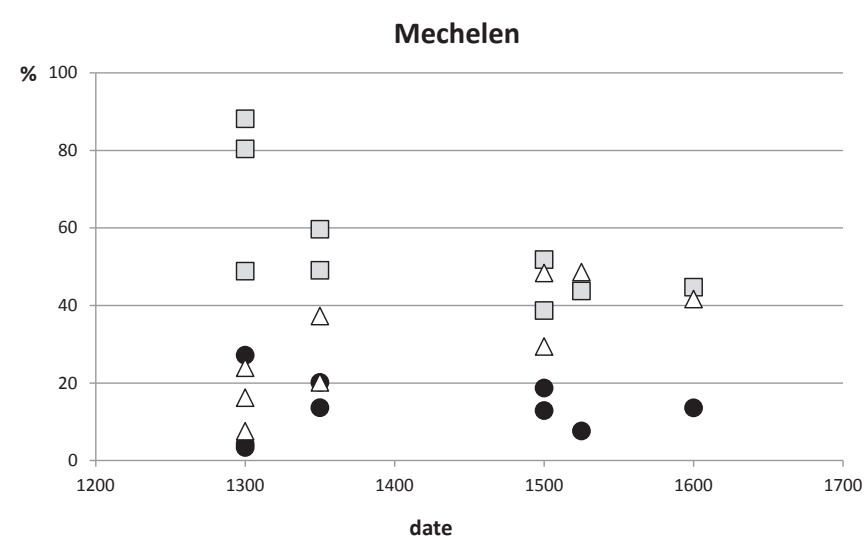

Fig. 5. Relative frequencies of pig (black dots), cattle (grey squares) and sheep (white triangles) for Mechelen. Data point $(1300,3)$ hides another for pig.

factors acting upon archaeological finds complexes, this is hardly a surprise; the ideal of statistical confidence will most probably never be reached.

Given the trends observed for Gent, Antwerpen and Mechelen, the most surprising result of the present survey is the absence of meaningful patterns for Brussel, the town best documented within the dataset (Fig. 7; Appendix A, Table 1). Cattle fluctuate around $56 \%$, sheep around $27 \%$ and pig around $17 \%$, with trends through time yet to be demonstrated. Since Brussel has the largest datasets, this lack of observed trends is certainly not the result of problems associated with small sample sizes.

Because at least some of the sites show diachronic differences in their faunal assemblages, any comparisons between them have to be made per time period. This has been done by averaging the relative frequencies of cattle, pig and sheep for the late medieval and the postmedieval assemblages (see Appendix A, Table 1, for the assemblages selected per period) and then comparing them in triplots (Fig. 8). For the late medieval period, it is clear that for all towns the average relative frequency of cattle remains exceeds $40 \%$, while percentages for sheep vary between 10 and $50 \%$ and those for pig reach $20 \%$ or higher in four of the nine towns (Brussel, Gent, Leuven, Aalst). For most of the towns, the values for the postmedieval period are markedly different. After $1500 \mathrm{AD}$, pig values above $20 \%$ no longer occur, while most of the sites show higher sheep and lower cattle values.

As discussed previously (see 3.), an exploration of the ratio of the find numbers of pig versus sheep $(\mathrm{P} / \mathrm{S})$ could present a way to eliminate some of the biases acting upon the overall dataset. Fig. 9 depicts these ratios for each of the locations within the nine towns.

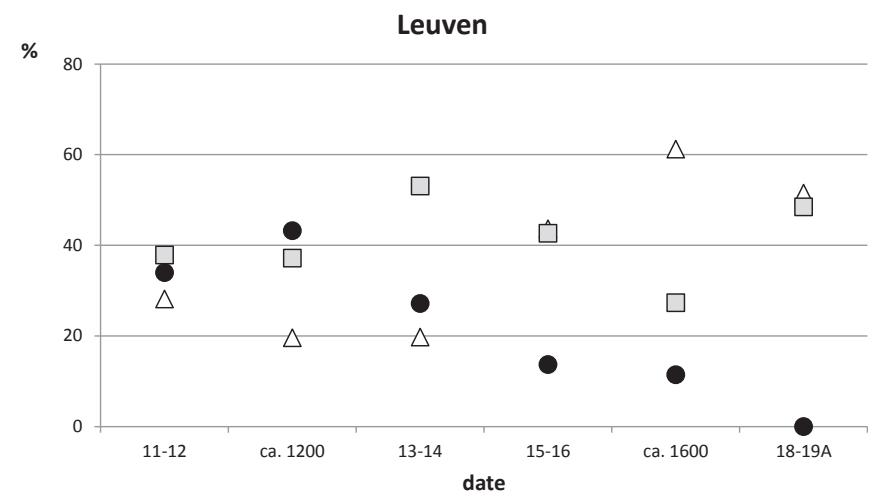

Fig. 6. Relative frequencies of pig (black dots), cattle (grey squares) and sheep (white triangles) for Leuven. 
pig
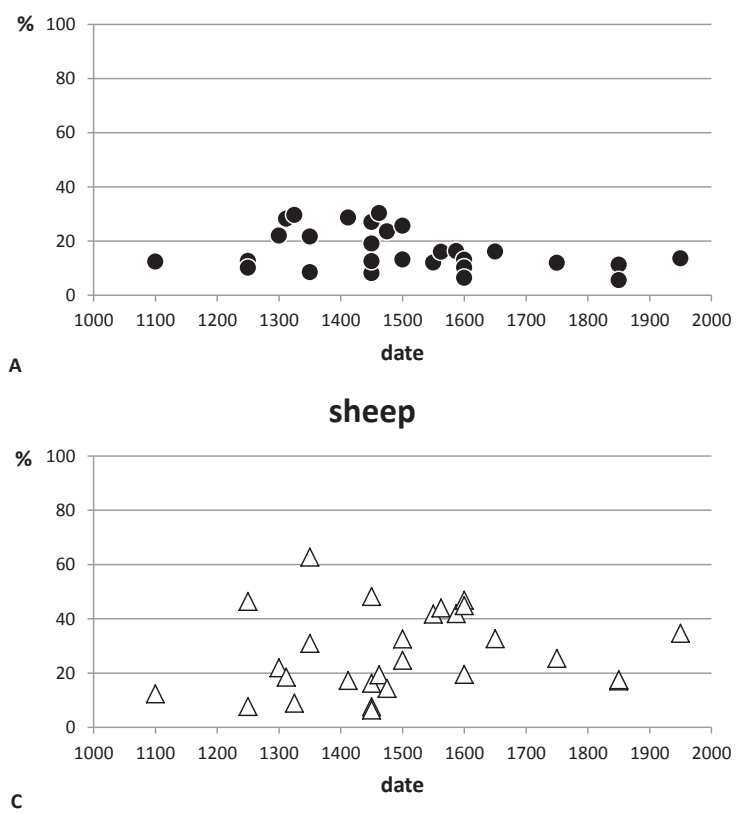
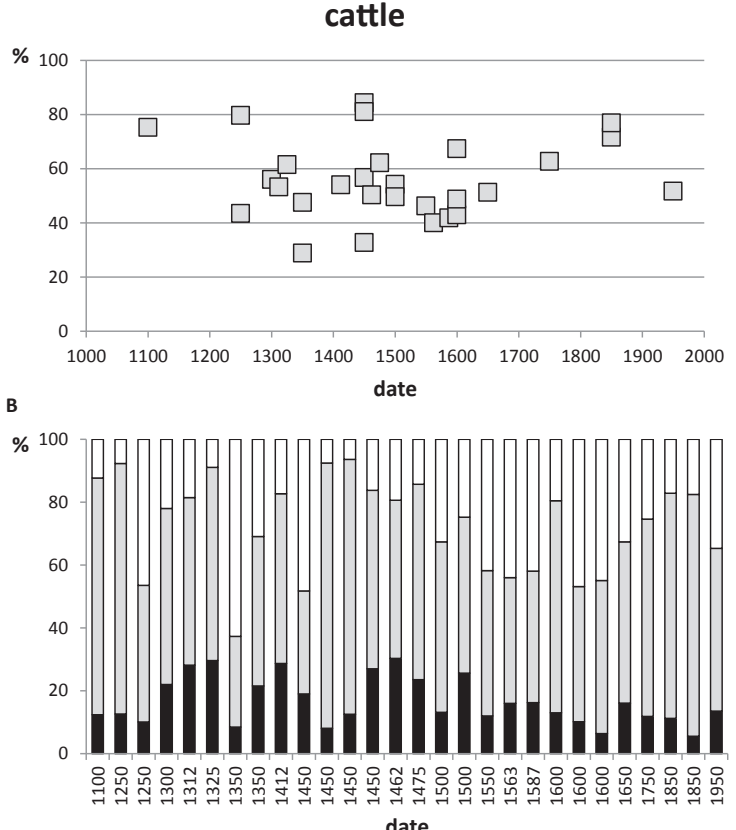

date

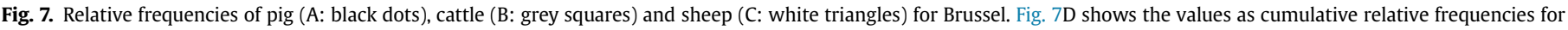
each of the 28 assemblages (black: pig, grey: cattle and white: sheep).

One high outlier, from Aalst 'Stadhuis pit Ia' $(\mathrm{P} / \mathrm{S}$ ratio $=7.0$, see Appendix A, Table 1), has been excluded from the graphs to avoid having to adjust the scale of the graphs for the other assemblages and thus crowd their data points. Even without a rigid statistical analysis, which is impossible in this case, a number of observations can be made. First, a number of the towns clearly and consistently show low $\mathrm{P} / \mathrm{S}$ values throughout the date range covered by their datasets. Such is the case for Ieper, Brugge, Antwerpen and Lier, and probably also Mechelen. Other sites show higher P/S values, including Gent, Leuven, Aalst and Brussel. Second, the graphs suggest that towards or shortly after $1500 \mathrm{AD}$, for all towns, the $\mathrm{P} / \mathrm{S}$ ratio drops to or dips below $1 / 1$.

Considering slaughter ages, where such data have been provided, the picture remains incomplete (see the references in Appendix 1 for the sites mentioned hereafter). Cattle consumed at the medieval sites seem to be represented by adult animals, while at postmedieval sites subadult animals (indicated by non-fused long bones) become more important and sometimes even dominate (i.e., in the postmedieval cesspits of Antwerpen). The dominance of old cattle in medieval contexts is e.g. illustrated by the finds from Gent - Vrijdagmarkt. The 16th century contexts from Sint-Katelijnewijk in Brussel contained more young cattle compared with older contexts from the same site. In the late 16th to early 17th century assemblage from Treurenberg (Brussel), it appears that $37 \%$ of the cattle remains are from calves, which is the highest proportion noted in this town. Sheep seem to be represented by older animals in both the medieval and postmedieval periods in all towns, although it was not possible to draw firm conclusions regarding slaughtering practices through time due to a lack of younger sites yielding sufficient observations (despite the relative increase in sheep consumption). The only site that allowed for the documenting of age at death patterns through time is the Arme Klaren at Brussel, where no shift comparable to the one seen in cattle seems to have occurred. The dominance of older sheep in medieval
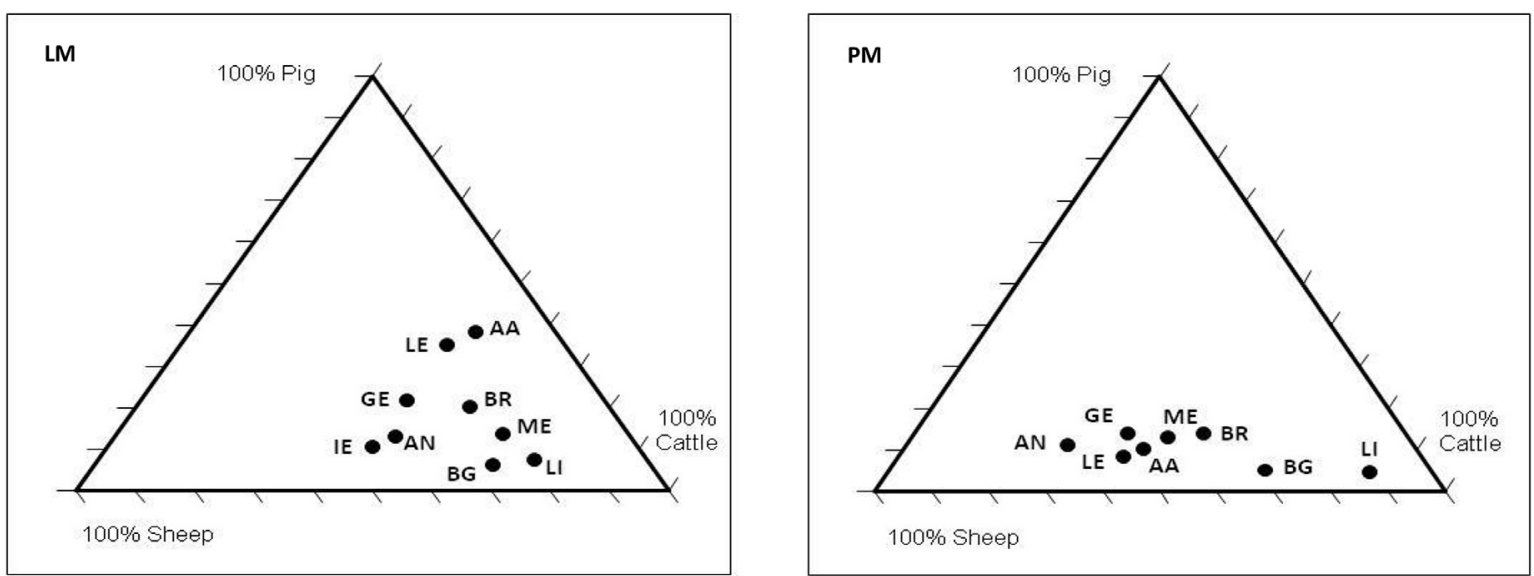

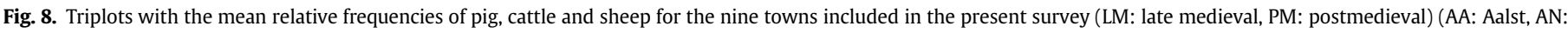
Antwerpen, BG: Brugge, BR: Brussel, GE: Gent, IE: Ieper, LE: Leuven, LI: Lier, ME: Mechelen). 


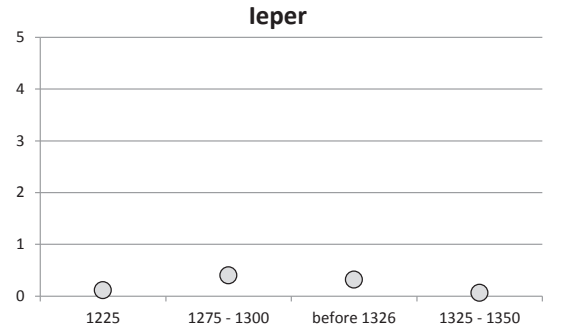

Lier

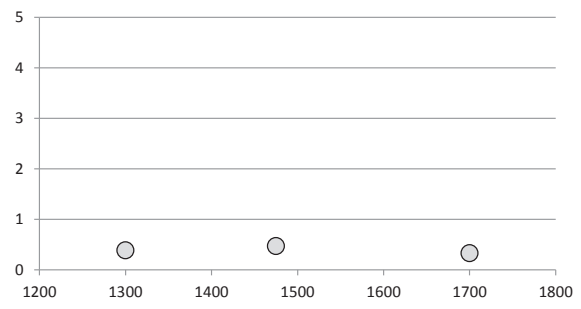

Gent

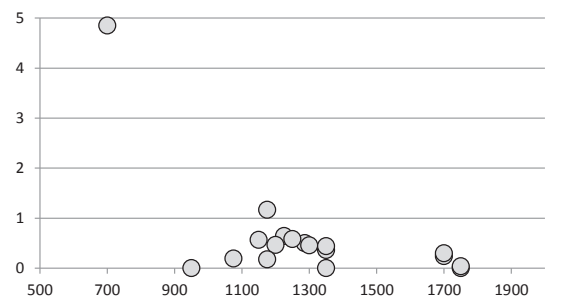

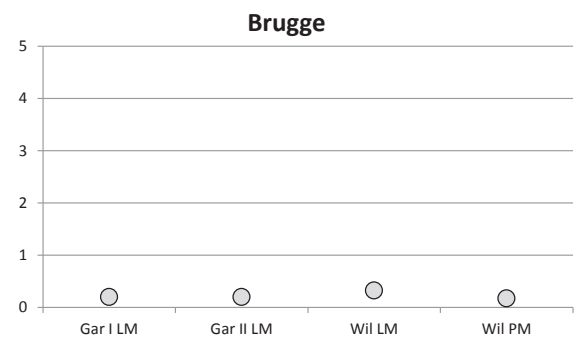
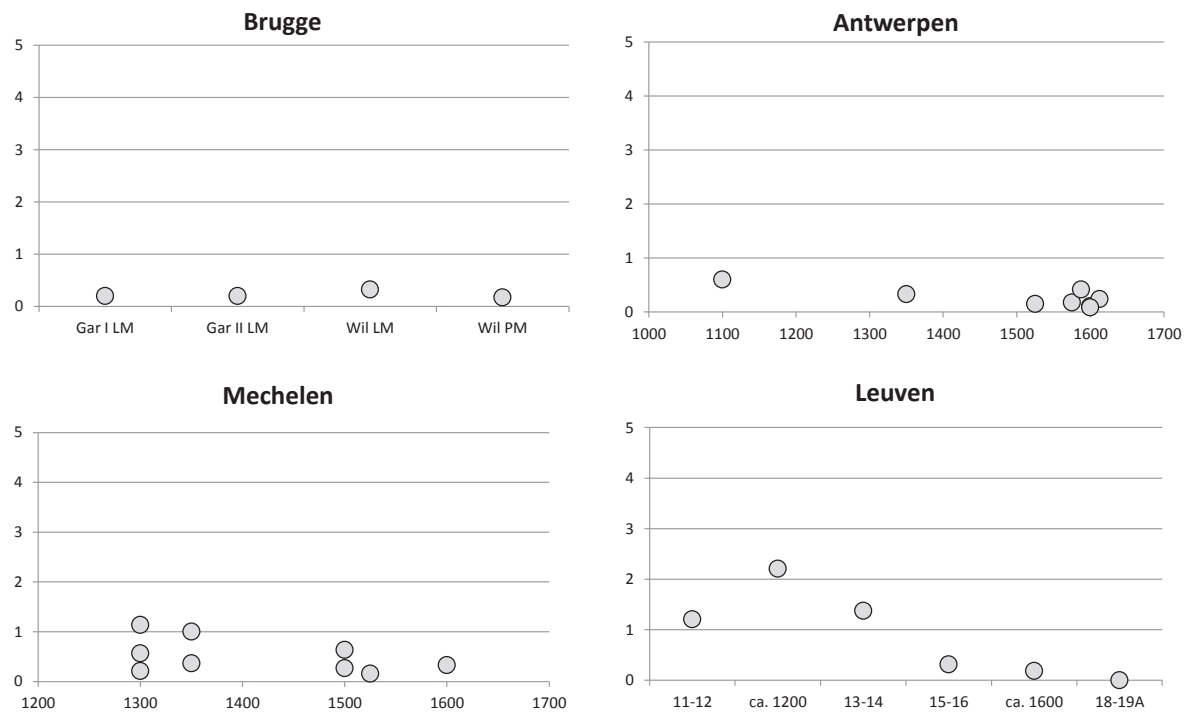

Aalst

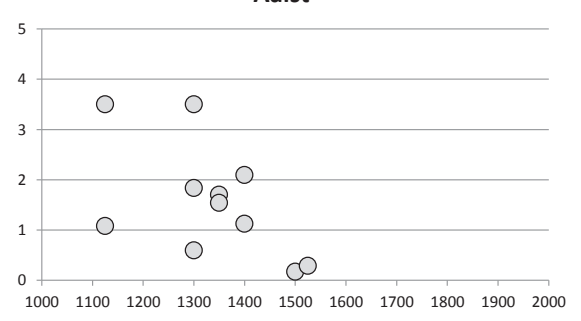

Leuven
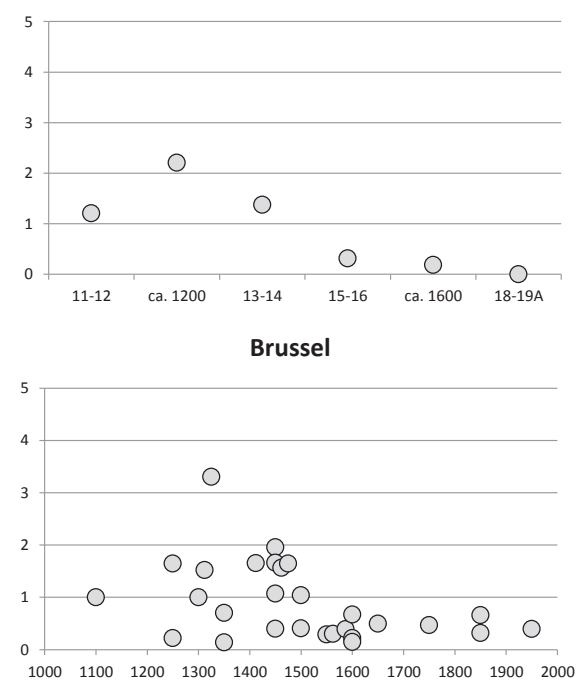

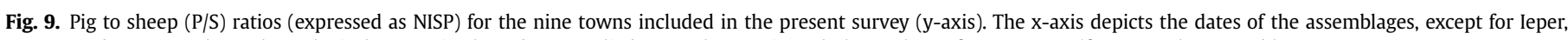

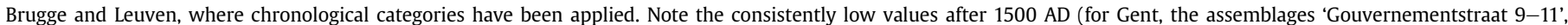
'Vrijdagmarkt 14' and 'Vrijdagmarkt 18' have been omitted due to their small sample sizes).

contexts is illustrated by the finds from Ieper, Gent - Vrijdagmarkt and Brussel in general. Finally, the data available show no particular diachronic trend for pigs, which are mainly slaughtered before two years of age.

\section{Discussion}

A number of interpretations can be made on the basis of the observations described above. First of all, it seems evident that the use of pigs as a means for the town inhabitants to achieve an independent meat supply must have been restricted. Otherwise pig relative frequencies would have been much higher in such booming medieval towns as Ieper, Brugge or Antwerpen (Fig. 8). Of course, a number of pigs will have been roaming the streets. At Gent, prohibitions ordering the townspeople to keep their pigs off the street were published until the end of the 18th century (Gent town archive: SAG, Oud Archief, Reeks 108, Voorgeboden). Still, the number of pigs cannot have been high enough to create a system of selfsufficiency for the town's meat supply. Taking into account the meat yield represented by each animal bone and the fact that all late medieval towns show cattle relative frequencies above $40 \%$, it is clear that this species was the major contributor to the urban meat market.

Because cattle were rarely being bred within the town walls, towns were indeed largely dependent upon their hinterland for their meat supply. This must have been equally true for pig (at least for a major part) and sheep. As mentioned before, cattle could have arrived at the town slaughterhouse from a long distance away, but pig and sheep most probably came from a region closer to town. In that respect, it is noteworthy that late medieval towns with lower pig relative frequencies (Fig. 8) are located near the Littoral and Alluvial District - more precisely, the marine polder area (Ieper, Brugge) - or bordering the Campine District (Mechelen, Lier). Antwerpen, another late medieval town with low pig percentages, is situated close to both the polders of the Scheldt estuary and to the Campine area (Fig. 2). The Littoral and Alluvial District evolved from an area of salt-marshes and salty meadows, ideal for sheep herding, into a polder zone intensively used for cattle breeding (see Müldner et al., 2014) (although sheep herding on dikes and other uncultivated grounds was maintained to a certain extent). Importantly, pig herding has never been a major activity in that part of the study area. The same is true for the Campine District, where the poor, sandy soils became covered with heath-land vegetation, suited for sheep herding but not for pig breeding. The geographical characteristics of the landscape near Ieper, Brugge, Antwerpen, Mechelen and Lier thus explain the composition of the animal component of their late medieval consumption refuse. Gent, Aalst, Brussel and Leuven are located in the Flemish and Hesbay Districts, where, originally, ample forest cover was present. This part of the study area was ideal for the traditional system of pig herding in the woods (well documented by historical sources: e.g., ten Cate, 1972; Laurans, 1975), which explains why, in the late medieval period, pig percentages are higher in these towns.

The fact that the observations for the late medieval towns suggest that meat consumption was significantly influenced by the geography of each town's hinterland implies that there must have been an economic link bringing animals from the countryside to the towns' markets. This may seem obvious, but it entails that, certainly in the case of the pigs arriving at Gent, Aalst, Brussel and Leuven, the feudal owners of the forests where pig herding took 
place must have organised surplus production with the aim of making a profit by sending animals to the towns. The traditional view of pig herding in the forest territories of the feudal lords stresses the importance of this activity for the self-sufficiency of the lords' castles (Ervynck et al., 2007), and this importance is reflected by high pig relative frequencies at castle sites (Ervynck, 2004). But the data gathered in this survey suggest that pig herding was also part of a market-driven, surplus-oriented animal economy. Historically, little is known about this aspect of the medieval economy. In general, the economic ways through which animals reached urban consumers need more clarification. Historical research will be essential in this respect, although archaeological information must certainly be taken into account. It is, e.g., interesting to note that the animal collections from such towns as Lier or Mechelen suggest that these sites were oriented towards the Campine area, rather than towards more southern territories, in order to organise part of their meat supply. Likewise, towns close to the coast seem to have been oriented more towards the polder area (the Littoral District) than towards the more forested areas to the south.

The postmedieval data gathered here show a shift towards higher relative frequencies for sheep and lower frequencies for pig and cattle (Fig. 8). For cattle, taphonomic factors could provide an explanation. As we mentioned earlier, it is plausible that through time - and certainly during the postmedieval period - fewer and fewer cattle bones arrived in the kitchens of individual households. In the case of pigs, the decline can be explained by the shift from herding the animals in the woods towards breeding pigs in confinement, near farmhouses - a process that was the result of deforestation and the evolution and gradual disappearance of the feudal system (Ervynck et al., 2007). This new system of pig breeding could not create the surplus that was needed to supply the towns; hence the decline in the relative frequencies for this species (Figs. 8 and 9). An alternative explanation, namely, that the habitation in the towns became too dense, making it impossible to continue to keep animals within the town walls, is contradicted by the fact that towns such as Aalst certainly still had a lot of open space in pre-industrial times (De Groote, 2013). Whether the rise in the relative frequency (percentage) of sheep reflects the real phenomenon of a rise in absolute frequency (e.g., expressed as meat weight consumed per capita) - and in turn reflects increased imports of sheep, e.g., from poorer soils - remains to be seen. As we stated previously, because the percentages are interdependent, when the absolute frequencies of pig and cattle remains decline, the relative frequency of sheep will rise, even when the absolute frequency remains constant. Further study is needed to establish whether or not there was an absolute increase in sheep.

Finally, the difference in slaughter ages for cattle (adult animals in medieval times and more subadult animals in the postmedieval period) can be explained by a shift from the 'recycling' of old animals that have served for traction, milk production and breeding, to the breeding of animals specifically for meat production (implying animals slaughtered at a younger age in order to optimize their meat yield as a function of food input). In the case of sheep, wool production must always have been the main purpose of keeping these animals, resulting in the ongoing slaughter of older animals. Pigs of course do not yield any secondary products and will thus always be slaughtered at rather young ages.

\section{Conclusions}

This new survey of archaeozoological data from eight Flemish towns and Brussel has revealed the existence of geographical and chronological differences in the urban meat supply. This represents considerable progress since the last survey (Ervynck, 1992) and demonstrates the benefit of the inclusion of more towns in the dataset. Gent is no longer the only site reasonably well documented archaeozoologically, having been joined by a number of other towns (Antwerpen, Mechelen, Leuven, Aalst) and having been surpassed in number of find contexts by Brussel. Of course, the chronological spread varies among towns, and in some cases this hampers comparisons with other towns. Because this is the result of differences in the historical developments of towns and in recent building activities, this situation is not easily remedied. The geographical distribution of the sites is also uneven, and it does not cover the entire study area. Again, the concentration of sites in the western and central parts is the result of historical developments and differences in recent archaeological activity. Further progress could be made by bringing together the data from the southern Low Countries and those from the northern part (the present-day Netherlands). A survey of that study area indeed reveals trends within towns, which at the same time also differ among sites (Lauwerier, 1997), presenting an interesting test for the ideas put forward in this paper.

Future archaeozoological analyses must include more than just relative frequencies or general age estimations. Detailed evaluation of age at death, sex distribution and pathologies will add to the story (when more large assemblages become available), as will provenance studies on the basis of stable isotope measurements. At the same time, the historical information available must be incorporated and the patterns observed must be synthesized within economic models for the relationship between town and countryside (O'Connor, 1992). However, in order to be able to do this per site, the assemblages should be critically re-evaluated, taking into account their detailed taphonomic and socio-economic contexts. At the moment, it remains a surprise to us that, given all the differences among the assemblages brought together in this survey, we were still able to reveal general patterns. This implies that, regardless of the context in which excavations have taken place (whether volunteer projects, excavations by town archaeologists, commercial archaeology, or otherwise), it remains useful to attempt to integrate the results obtained.

\section{Acknowledgements}

Without naming anybody specifically (see Appendix A, Table 1), the authors wish to thank the many urban archaeologists from Flanders and Brussels who, over the years, have recovered faunal assemblages, often in difficult working conditions, and made them available for study. The colleagues working on these 'bone collections' are equally acknowledged. Thanks also go to Bea De Cupere for providing the map, Luc Devriese for drawing attention to the document from the town archive of Gent, Jan Bastiaens for geographical information, and the anonymous reviewers for their useful remarks. Suzanne Needs-Howarth reviewed and corrected the English. The contribution of Wim Van Neer to this paper presents research results of the Interuniversity Attraction Poles Programme - Belgian Science Policy.

\section{Appendix A. Supplementary data}

Supplementary data related to this article can be found at http:// dx.doi.org/10.1016/j.quaint.2017.02.004.

\section{References}

Abel, W., 1961. Rinderhaltung in Grünlandgebieten im Mittelalter. Z. Tierzücht. Züchtungsbiol. 76, 88-100.

Albarella, U., 2005. Meat production and consumption in town and country. In: Giles, K., Dyer, C. (Eds.), Town and Country in the Middle Ages: Contrasts, Contacts and Interconnections, 1100-1500, Society for Medieval Archaeology Monograph, 22. Maney, Leeds, pp. 131-148. 
Arts, N., Huijbers, A., Leenders, K., Schotten, J., Stoepker, H., Theuws, F., Verhoeven, A., 2007. De middeleeuwen en vroegmoderne Tijd in Zuid-Nederland (versie 1.0). Nationale Onderzoeksagenda Archeologie. http:// archeologieinnederland.nl/bronnen-en-kaarten/nationale-onderzoeksagendaarcheologie-10.

Bartosiewicz, L., 1995. Animals in the Urban Landscape in the Wake of the Middle Ages [BAR International Series]. Tempus Reparatum, Oxford.

De Groote, K., 2013. De stadswording van Aalst, of hoe een Merovingische nederzetting uitgroeide tot een laatmiddeleeuwse stad. M\&L - Monumenten, Landschappen en Archeologie 32 (1), 4-32.

Dyer, C., 1997. Do household accounts provide an accurate picture of late medieva diet and food culture? In: Rassart-Eeckhout, E., Sosson, J.-P., Thiry, Cl., Van Hemelryck, T. (Eds.), La vie matérielle au Moyen Âge. L'apport des sources littéraires, normatives et de la pratique. Université Catholique de Louvain Louvain-la Neuve, pp. 109-124.

Ervynck, A., 1992. The Economy of Food in Medieval Towns: Getting Rid of the Simple Explanations. Medieval Europe 1992. Pre-printed Papers, Volume 1. University of York, York, pp. 133-138.

Ervynck, A., 1997. Following the rule? Fish and meat consumption in monastic communities in Flanders (Belgium). In: De Boe, G, Verhaeghe, F. (Eds.), Environment and Subsistence in Medieval Europe [Papers of the 'Medieval Europe Brugge 1997' Conference 9]Instituut voor het Archeologisch Patrimonium, Zellik, pp. 67-81.

Ervynck, A., 2004. Orant, pugnant, laborant. The diet of the three orders in the feudal society of medieval north-western Europe. In: O'Day, S.J., Van Neer, W. Ervynck, A. (Eds.), Behaviour behind Bones. The Zooarchaeology of Ritual, Religion, Status and Identity. Oxbow Books, Oxford, pp. 215-223.

Ervynck, A., Boudin, M., Van den Brande, T., Van Strydonck, M., 2014. Dating human remains from the historical period in Belgium. Diet changes and the impact of marine and freshwater reservoir effects. Radiocarbon 56, 779-788.

Ervynck, A., Lentacker, A., Müldner, G., Richards, M., Dobney, K., 2007. An investigation into the transition from forest dwelling pigs to farm animals in medieval Flanders, Belgium. In: Albarella, U., Dobney, K., Ervynck, A., Rowley-Conwy, P. (Eds.), Pigs and Humans. 10,000 Years of Interaction. Oxford University Press, Oxford, pp. 171-193.

Gijsbers, W.M., 1999. Kapitale Ossen. De Internationale Handel in Slachtvee in Noordwest-Europa 1300-1750. N.W. Posthumus Reeks/Verloren, Hilversum.

Gruwier, B., 2012. De dierlijke resten. In: Smeets, M., Vander Ginst, V. (Eds.), Het archeologisch onderzoek op het Fochplein te Leuven [Studiebureau Archeologie Archeo-rapport 94]. Studiebureau Archeologie bvba, Kessel-Lo, pp. 303-364.

Laurans, R., 1975. L'élevage du porc à l'époque médiévale. In: Pujol, R. (Ed.), L'homme et l'animal. Premier colloque d'ethnozoologie. Institut International d'Ethnosciences, Paris, pp. 523-534.

Lauwerier, R.C.G.M., 1997. Faunal remains from Dutch medieval towns, a survey. Anthropozoologica 25-26, 479-486.

Massart, J., 1910. Esquisse de la géographie botanique de la Belgique. Recueils de l'Institut Botanique de Bruxelles, Vol. 7bis. H. Lamertin, Bruxelles.
Müldner, G., Britton, K., Ervynck, A., 2014. Inferring animal husbandry strategies in coastal zones through stable isotope analysis: new evidence from the Flemish coastal plain (Belgium, 1st-15th century AD). J. Archaeol. Sci. 41, 322-332.

O'Connor, T.P., 1992. Provisioning urban communities: a topic in search of a model. Anthropozoologica 16, 101-106.

O'Connor, T.P., 2003. The Analysis of Urban Animal Bones Assemblages: a Handbook for Archaeologists [The Archaeology of York, Volume 19: Principles and Methods, Fascicle 2.]. York Archaeological Trust, York.

O'Connor, T., 2013. Livestock and deadstock in early medieval Europe from the North Sea to the Baltic. Environ. Archaeol. 15 (1), 1-15.

O'Connor, T., 2014. Livestock and animal husbandry in early medieval England. Quat. Int. 346, 109-118.

Pounds, N.J.G., 2005. The Medieval City [Greenwood Guides to Historic Events of the Medieval World]. Greenwood Press, Westport.

Slechten, K., 2004. Namen Noemen: Het CAI-thesaurusproject. In: CAI-i. De Opbouw van een Archeologisch Beleidsinstrument [IAP-Rapporten 14]. Instituut voor het Archeologisch Patrimonium, Brussel, pp. 49-54.

Tack, G., Van Den Bremt, P., Hermy, M., 1993. Bossen van Vlaanderen: Een historische ecologie. Davidsfonds, Leuven.

Tanghe, M., 1975. Atlas van België. Fytogeografie. Commentaar bij de bladen 19A en 19B (Fytogeografie I en II). Nationaal Comité voor Geografie, Commissie voor de Nationale Atlas, Brussel.

ten Cate, C.L., 1972. Wan God Mast gift... Bilder aus der Geschichte der Schweinezucht im Walde. Centre for Agricultural Publishing and Documentation, Wageningen.

Van der Plaetsen, P., 1985. Beestig Gent - Archeozoölogie in een stad. Stadsarcheologie. Bodem en Monument in Gent 9 (3), 12-26.

Van der Plaetsen, P., 1986. Vlees en Vis. In: Laleman, C., Raveschot, P. (Eds.), Wat een leven binnen die muren. Gent 1100-1350, pp. 97-100. Gent.

Van Uytven, R., 1985. L'approvisionnement des villes des anciens Pays-Bas au Moyen age. In: L'approvisionnement des villes de l'Europe occidentale au Moyen Age et aux temps modernes: cinquièmes Journées internationales d'histoire, 16-18 septembre 1983/Centre culturel de l'Abbaye de Flaran. Comité départemental du tourisme du Gers, Auch, pp. 75-116.

Verhulst, A., 1990. Précis d'histoire rurale de la Belgique. Editions de l'Université de Bruxelles, Bruxelles.

Verhulst, A., 1995. Landschap en Landbouw in Middeleeuws Vlaanderen. Gemeentekrediet, Brussel.

Verhulst, A., 1999. The Rise of Cities in North-West Europe. Cambridge University Press, Cambridge.

Woolgar, C.M., 1992-1993. Household Accounts from Medieval England [Records of Social and Economic History, New Series, 17-18]. Oxford University Press, Oxford.

Zajac, A., Deckmyn, Y., 2009. Ghent: water as a structuring element of urbanity. In: Feyen, J., Shannon, K., Neville, M. (Eds.), Water and Urban Development Paradigms: towards an Integration of Engineering, Design and Management Approaches. Taylor \& Francis Group, London, pp. 143-150. 